\title{
RESÚMENES/ABSTRACTS
}

\section{UN ACERCAMIENTO A LAS MARCAS ANIMADAS}

\section{Gretell Leyva Salazar}

Se vislumbra que las aún novedosas marcas compuestas por imágenes en movimiento puedan gozar de mayor aceptación en un futuro cercano. Es por ello por lo que este trabajo tiene como objetivo realizar un acercamiento a la figura de las marcas animadas, también conocidas como marcas en movimiento o de multimedia. Se propone centrar el análisis en la viabilidad jurídica para su protección, el reconocimiento internacional del que gozan en diferentes latitudes, algunas observaciones respecto a la forma en que pueden cumplir los requisitos de representación gráfica y distintividad para el registro marcario, así como una breve referencia a las potencialidades para la protección de estas marcas en Cuba.

Palabras clave: Marcas, marcas no tradicionales, marcas animadas o en movimiento, representación gráfica, distintividad.

\section{An APPROACH TO MOVEMENT TRADEMARKS}

It is envisaged that trademarks composed by moving images, which are still very novel, may enjoy greater acceptance in the near future. Hence, this work aims to make an approach to the figure of animated trademarks, also known as movement or multimedia trademarks. The analysis in this occasion will be focus on the legal feasibility for its protection, the international recognition that they enjoy in different latitudes, some observations regarding the way in which they can fulfill the requirements of graphic representation and distinctiveness for the trademark registration; as well as a brief reference to the potentialities for the protection of these kind of trademarks in Cuba.

Keywords: Trademarks, non-traditional trademarks, animated or movement trademarks, graphic representation, distinctiveness. 


\section{INCORPORANDO LOS RIESGOS DEL SIGLO XXI \\ EN LA VALUACIÓN DE MARCAS}

\section{Luis Fernando Samper}

Los intangibles son los activos más valiosos de las compañías. Sin embargo, los métodos tradicionales de valuación de marcas, desarrollados en el siglo xx, no incorporan los riesgos asociados con la globalización, el empoderamiento de los consumidores y las mayores exigencias de la sociedad a las empresas. Se propone una metodología para cuantificar los riesgos del "diálogo social" y su impacto en la reputación y en los negocios de las marcas e industrias, así como para calificar la calidad de sus políticas de sostenibilidad. De esta manera se miden más acertadamente los riesgos de marca y se obtiene una valuación que refleja las condiciones de operación del siglo xxi.

Palabras clave: Valor de marca, intangibles, diálogo social, riesgo de marca, sostenibilidad, metodologías de valuación.

\section{MEASURING 2I $\mathrm{I}^{\mathrm{ST}}$ - CENTURY RISKS IN BRAND VALUATION}

Intangibles are the most valuable assets of companies. However, the traditional methods applied to the valuation of brands, developed in the twentieth century, do not incorporate the greater risks associated with globalization, the empowerment of consumers and the greater demands of society on companies. The article proposes a methodology to quantify the "social dialogue risks", and their impact on the reputation of business of brands and industries, and to measure the quality of their sustainability policies. In this way, brand risks are more accurately measured, and a valuation is obtained that reflects the reality of the 21 st century.

Keywords: Brand value, intangibles, social dialogue, brand risks, sustainability, valuation methodologies.

\section{LOS DERECHOS MORALES DE AUTOR COMO DERECHOS FUNDAMENTALES EN COLOMBIA}

\section{Daniela Bernal Sánchez Carlos Conde Gutiérrez}

Los derechos de autor protegen obras artísticas, literarias y científicas. Esta protección abarca dos tipos de derechos: morales y patrimoniales. Pese a esto, existe una prevalencia de los derechos patrimoniales de autor frente a los morales. Esto se debe a la influencia del copyright, el cual somete la existencia de los derechos 
morales a los derechos patrimoniales, aspecto que contradice los elementos esenciales del derecho moral: perpetuidad, inalienabilidad e irrenunciabilidad, elementos propios de las legislaciones Civil Law, incluyendo a Colombia. No obstante, la Corte Constitucional de Colombia ha ido más allá, ha elevado estos derechos a la categoría constitucional de derechos fundamentales y ha garantizado de esa manera su prevalencia.

Palabras clave: Corte Constitucional, copyright, derechos de autor, derechos morales, derechos patrimoniales, derechos fundamentales, Dirección Nacional de Derechos de Autor.

\section{MORAL AUTHOR RIGHTS AS FUNDAMENTAL RIGHTS IN COLOMBIA}

Authors rights protects artistic, literary and scientific works. This type of IP encompasses two types of rights: moral and patrimonial. Despite of the fact of this, there is a prevalence of author's economic rights against moral ones. This is due to the influence of Copyright, which subjects the existence of moral rights to patrimonials. This aspect contradicts the essential characteristics of moral rights, perpetuity, inalienability and irrenunciability, elements of the legislation deriving from the Civil Law, including Colombia. Nevertheless, the Colombian Constitutional Court has gone further as it has elevated moral rights to the constitutional category of human (fundamental) rights, thus guaranteeing its prevalence.

Keywords: Authors rights, Constitutional Court, copyright, moral rights, patrimonial rights, fundamental rights, Colombian National Copyright Office.

\section{De cultura a mercancía. la CONFiguración \\ DE LA PROPIEDAD INTELECTUAL EN EL MARCO \\ DE LA ORGANIZACIÓN MUNDIAL DEL COMERCIO}

\section{Joan Ramos Toledano}

El presente trabajo trata de analizar las consecuencias de regular la propiedad intelectual en un marco pensado para el comercio, como la Organización Mundial del Comercio. La propiedad intelectual regula las expresiones artísticas, intelectuales o creativas -elementos fundamentales para el desarrollo de una sociedad-, y, sin embargo, su faceta de mercancía ha resultado decisiva a la hora de establecer la regulación internacional, basada en actitudes de imposición por parte de países poderosos frente a Estados menos desarrollados. En todo ese proceso, como se verá, la propia configuración de la OMC y sus dinámicas de funcionamiento han resultado fundamentales. 
Palabras clave: Mercantilización, creación artística, legislación internacional, organizaciones internacionales.

\section{From Culture to COMmodity. The Configuration OF INTELLECTUAL PROPERTY WITHIN THE FRAMEWORK OF THE WORLD TRADE ORGANIZATION}

The present paper tries to briefly analyse the consequences of regulating intellectual property in a framework designed for trade, such as the World Trade Organization. Intellectual Property Law regulates artistic, intellectual and creative expressions -which are fundamental elements for the optimal development of a society-and yet the commodity facet of those expressions has been decisive in establishing international regulation, based on attitudes of imposition by powerful countries against less developed countries. Throughout this process, as this paper tries to analyse, the very configuration of the WTO and its dynamics of operation has been fundamental.

Keywords: Commodification, artistic creation, international legislation, international organizations.

\section{LaS MARCAS OLFATIVAS EN COLOMbia}

\section{Daniel Barrios Espinosa}

El objetivo del presente artículo de investigación es indagar sobre la posibilidad de obtener el registro de una marca olfativa en Colombia. Para esto, recogiendo opiniones de la doctrina, de diferentes autoridades y exponiendo ejemplos de distintas jurisdicciones, se explican los conceptos de marca y marcas no tradicionales, así como sus elementos. De la misma manera, se explica el concepto de "marcas olfativas" y se evidencian los problemas que presenta su registro. Se hace un recuento de lo ocurrido con las marcas olfativas en Colombia, analizando varios conceptos y resoluciones de la autoridad competente. Finalmente, se plantean varias conclusiones, en las que se responde negativamente al objetivo del texto.

Palabras clave: Marcas olfativas, marcas no tradicionales, marcas, propiedad industrial, registro de marcas, registrabilidad de marcas olfativas en Colombia.

\section{Scent trademarks in Colombia}

The objective of the present investigation article is to figure out if it's possible to obtain the registration of a scent mark in Colombia. In order to do this, the concept and elements of trademarks and non-traditional trademarks are explained 
by gathering the opinions of the doctrine and different authorities around the world, just as examples from several jurisdictions.

Subsequently, scent marks are explained, such as their problems in terms of registration. The different moments of this trademarks in Colombia are described, analyzing various concepts and resolutions of the competent authority. Finally, conclusions are presented, in which the objective of the article is answered negatively.

Keywords: Scent marks, non-traditional trademarks, trademarks, industrial property, registry of marks, registrability of scent marks in Colombia.

\section{THE TRADE SECRETS PROTECTION IN U.S. AND IN EUROPE: A COMPARATIVE STUDY}

\section{Chiara Gaido}

Only by deeply understanding the new laws that govern trade secrets protection in the United States and Europe, companies will be able to effectively protect their own trade secrets. The purpose of this paper is to highlight the similarities and differences between both regulations to give useful guidelines to international companies who deal in both geographical areas. Therefore, the paper will focus first on the economic value of trade secrets and the costs related to cybercrime and cyberespionage. Then, it will analyze the US and EU historical legal backgrounds that brought to the adoption of both laws. Finally, this article will make a comparative analysis of the provisions in each law. Hence, the paper makes potential suggestions for companies that deal in both regimes.

Keywords: Trade secrets, information, know how, cybercrime, cyberespionage, DTSA, TRIPS, EC Directive 2016/943 May 2016

\section{LA PROTECCIÓN DE LOS SECRETOS EMPRESARIALES}

EN ESTADOS UNIDOS Y EUROPA: UN ESTUDIO COMPARADO

Solo mediante la comprensión profunda de las nuevas leyes que rigen la protección de los secretos empresariales en Estados Unidos y Europa, las empresas podrán proteger eficazmente sus propios secretos empresariales. El propósito de este documento es destacar las similitudes y diferencias entre ambas regulaciones para brindar pautas útiles a compañías internacionales que trabajan en ambos mercados. Por lo tanto, el documento se centrará primero en el valor económico de los secretos empresariales y los costos relacionados con el cibercrimen y el ciberespionaje. Luego, analizará los antecedentes históricos de las legislaciones de Estados Unidos y la U.E. que llevaron a la adopción de ambas leyes. Finalmente, este artículo hará un 
análisis comparativo de las disposiciones en cada ley. Por lo tanto, el documento hace sugerencias potenciales para las empresas que operan en ambos regímenes.

Palabras clave: Secretos empresariales, información, know how, cibercrimen, ciberespionaje, DTSA, ADPIC, Directiva EC 2016/943 de mayo de 2016.

\author{
7. Limitaciones de las Cláusulas Contractuales \\ PARA DETERMINAR LA NATURALEZA JURÍDICA DE LA INFORMACIÓN \\ Y PARA PROTEGER LOS SECRETOS EMPRESARIALES
}

\title{
Nelson Remolina Angarita Gabriela Tafur Nader
}

Con base en la regulación colombiana y el estudio de algunas sentencias de la Superintendencia de Industria y Comercio, este texto analiza los requisitos jurídicos para que cierta información pueda considerarse como secreto empresarial. De ahí se argumenta que una cláusula contractual por sí sola no determina la información que puede considerarse como un secreto empresarial, ya que la autonomía de la voluntad no tiene el poder de desconocer la naturaleza jurídica de la información.

Palabras clave: Secretos empresariales, información, cláusulas de confidencialidad, medidas de protección de los secretos empresariales, límites a la autonomía de la voluntad, naturaleza jurídica de la información.

\author{
The Limitations OF CONTRACTUAL ClaUSES \\ TO DETERMINE THE LEGAL NATURE OF INFORMATION \\ AND TO PROTECT TRADE SECRETS
}

This text analyses the legal requirements for information to be considered a trade secret based on Colombian regulations and rulings issued by the Superintendencia de Industria y Comercio. A contractual clause, by itself, does not have the power to define the information that can be considered a trade secret because freedom of choice cannot disregard the legal nature of the information.

Keywords: Trade secrets, information, confidentiality clauses, protection measures of trade secrets, limits to the freedom of contract, legal nature of information. 


\section{LA MODA Y LOS PRODUCTOS DE LUJO EN LOS MERCADOS ONLINE: UNA MIRADA DESDE LA PERSPECTIVA DEL DERECHO MARCARIO}

\section{Brenda Salas Pasuy}

La comercialización de la moda y de los productos de lujo tradicionalmente se ha hecho en grandes superficies, boutiques o en tiendas. Sin embargo, la moda quiere expandirse a los mercados online. Diferentes inquietudes surgen respecto de estos, a saber, la definición de la responsabilidad por las infracciones a los derechos marcarios y el rol de los sujetos que participan en la distribución online, es decir, del infractor directo y del prestador e-commerce. La industria de la moda y de los productos de lujo no es ajena a este cuestionamiento, es más, se trata de uno de los sectores que han sido afectados por la piratería y el contrabando en Internet. El propósito de este artículo es identificar la respuesta ofrecida en distintos regímenes jurídicos, como el estadounidense, el europeo y el colombiano.

Palabras clave: Moda, productos de lujo, mercados online, prestador e-commerce, marcas, responsabilidad.

FASHION AND LUXURY PRODUCTS IN THE ONLINE MARKETS:

A VIEW FROM TRADEMARK LAW

Traditionally marketing fashion and luxury products are associated with large spaces such as malls, boutiques or fashion stores. However, fashion industry wants to expand to "online markets". Several concerns arise with this expansion like the definition of the liability for trademark infringements and the role played by different parties in the online distribution such as the direct infringer and the e-commerce provider. Fashion industry is not strange to this matter, furthermore, it's one of the fields in which piracy and counterfeiting has been produced in higher quantities on the Internet. The purpose of this article is to identify the answer given by the law in the United States, in Europe and in Colombia.

Keywords: Fashion, luxury products, online markets, e-commerce provider, trademark, liability. 


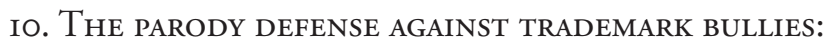

ANALYSIS OF THE LOUIS VUITTON vs. MOB CASE

\section{Daniela Molano Lozano}

The present note aims to give a better understanding of parody as an exception to the exclusive rights provided to copyright holders and trademark owners. With this purpose, the note uses the Louis Vuitton vs. мов case as a reference.

Keywords: Parody, Intellectual property, Luis Vuitton, мов, Famous marks, Supreme Court, copyright infringement, trademark infringement, trademark dilution.

\section{LA PARODIA COMO DEFENSA CONTRA LOS HOSTIGADORES MARCARIOS: ANÁLISIS DEL CASO LOUIS VUITTON VS. MOB}

La presente reseña pretende desarrollar y dar una mejor comprensión de la figura de la parodia como una excepción a los derechos exclusivos otorgados al titular de las obras protegidas por derechos de autor o de marcas protegidas, lo anterior mediante el análisis específico del caso Louis Vuitton contra мов.

Palabras clave: Infracción derechos de autor, parodia, propiedad intelectual, Louis Vuitton, dilución de marca, infracción marcaría, мов, Marcas notorias, Corte Suprema de los Estados Unidos 